\title{
The Effects of Plant Secondary Metabolites from Coniferous Needle Leaf Litter on the Leaf Litter Decomposition of Betula albo-sinensis Burk
}

(Kesan Metabolit Tumbuhan Sekunder daripada Sampah Daun bak Jarum Konifer pada Penguraian Sampah Dedaun Betula albo-sinensis Burk)

\section{Xiaoxi Zhang, Hui LiU, WenXing Zhou, Jiajia Li, Hangyu Lei, YongKang Ji, Boya Wang \& ZengWen LiU*}

\begin{abstract}
In this study, leaf litters of Betula albo-sinensis and 5 coniferous species were used as samples. The B. albo-sinensis leaf litter was buried in soil and termly treated with the water extracts of five types of coniferous leaf litter for a 6-month simulation decomposition experiment. The dynamics of mass loss and nutrients $(C, N, P$, and $K)$ content of leaf litter and the soil enzymatic activities were measured to investigate the effects of plant secondary metabolites (PSM) from coniferous leaf litters on the decomposition processes of $\mathrm{B}$. albo-sinensis leaf litter. The results indicated that the extracts of Pinus tabuliformis, Platycladus orientalis, P. armandii and Larix principis-rupprechtii leaf litters significantly inhibited the whole decomposition process and overall nutrients release of $\mathrm{B}$. albo-sinensis leaf litter, while the extracts of Picea asperata leaf litter exhibited no significant influence. The general suppression of PSM on the soil sucrase, carboxymethyl cellulase and $\beta$-glucosidase activities might be the main reason leading to the inhibitory effects of the extracts of $\mathrm{P}$. tabuliformis, P. orientalis, P. armandii and L. principis-rupprechtii leaf litter. The species causing inhibitory effects, especially L. principis-rupprechtii, was not recommended to be planted mixed with $\mathrm{B}$. albo-sinensis, or their planting density should be lower in the mixed forests.
\end{abstract}

Keywords: Leaf litter decomposition; nutrient release; secondary metabolites; soil enzymatic activities

\section{ABSTRAK}

Dalam kajian ini, sampah dedaun bagi Betula albo-sinensis dan lima spesies konifer telah digunakan sebagai sampel. Sampah dedaun B. albo-sinensis telah ditanam di dalam tanah dan dirawat dengan ekstrak air daripada lima jenis sampah dedaun konifer untuk uji kaji penguraian simulasi selama 6 bulan. Dinamik kehilangan jisim dan kandungan nutrien (C, $N, P$ dan $K$ ) sampah dedaun dan aktiviti enzim tanah diukur untuk mengkaji kesan metabolit sekunder tumbuhan (PSM) daripada sampah dedaun konifer dalam proses penguraian sampah dedaun B. albo-sinensis. Hasilnya menunjukkan bahawa ekstrak sampah dedaun Pinus tabuliformis, Platycladus orientalis, P. armandii dan Larix principis-rupprechtii menghalang proses penguraian keseluruhan dan penyebaran nutrien keseluruhan B. albo-sinensis secara signifikan, manakala ekstrak sampah dedaun Picea asperata tidak menunjukkan kesan yang signifikan. Penekanan umum PSM ke atas aktiviti sukrase, karboksimetil selulase dan aktiviti $\beta$-glucosidase tanah mungkin menjadi sebab utama yang membawa kepada kesan perencatan ekstrak sampah dedaun P. tabuliformis, P. orientalis, P. armandii dan L. principis-rupprechtii. Spesies yang menyebabkan kesan perencatan, terutamanya L. principis-rupprechtii adalah tidak disarankan untuk ditanam bercampur dengan B. albo-sinensis atau ketumpatan penanamannya harus lebih rendah di dalam hutan bercampur.

Kata kunci: Aktiviti enzimatik tanah; metabolit sekunder; pelepasan nutrien; penguraian sampah dedaun

\section{INTRODUCTION}

Leaf litter decomposition is one of the key factors affecting material cycling and energy flow in an ecosystem, and it also plays an important role in influencing the supply of nutrients and the composition of soil organic matter in forests. Consequently, leaf litter decomposition has been widely studied during recent decades (Gartner \& Cardon 2004; Ghasemi-Aghbash et al. 2015; Purahong et al. 2014). In natural conditions, different leaf litter types are mixed together, which causes significant fluctuations in the leaf litter nutrient conditions and their surrounding soil micro-environments; thus, 'non-additive' phenomena were frequently observed during the decomposition of these leaf litter mixtures (De Marco et al. 2011; Duan et al. 2013; Gartner \& Cardon 2004; Mao et al. 2015). Many investigations have demonstrated that mixed decomposition could change the physical spatial structure of leaf litter and increase the chemical diversity of decomposing substrate. This might, in turn, provide a more suitable microhabitat and more heterogeneous nutrients for decomposers, ultimately leading to changes in decomposer populations and biodiversity (Chapman et al. 2013; Liu et al.2010). Meanwhile, mixed-leaf litter decomposition can change the activities of several types of soil enzymes ( $\mathrm{Li}$ et al. 2016b; Li \& Liu 2013), which might accelerate or hinder leaf litter decomposition. Furthermore, because of 
the differences in the substrate quality of leaf litters, the nutrients controlling the decomposition processes, such as $\mathrm{N}$ and $\mathrm{P}$, might be transferred from nutrient-rich leaf litter to nutrient-poor leaf litter, thus, affecting the overall decomposition of leaf litter mixtures (Hättenschwiler et al. 2005). In addition, the various plant secondary metabolites (PSM) in the foliar leaf litter are also regarded as important factors causing the 'non-additive' phenomena observed during the decomposition of mixed leaf litter (Chomel et al. 2016).

The PSM contained in leaf litter might be released to the surrounding environment by leaching or leaf litter decomposition. In addition to their allelopathic effects on other plants, the PSM might also significantly affect the biological and chemical characteristics of soil. For instance, Mierziak et al. (2014) stated that phenolic compounds can significantly suppress the activities of fungi, inhibiting their reproduction and growth, and they also cause remarkable disruptions in the physiological activity of bacteria. Terpenes were reported to show accelerating/inhibitory dual effects on soil microbes, which were dependent on their type and concentration in the environment (Adamczyk et al. 2015). Alkaloids were confirmed as toxic compounds capable of decreasing the populations and activities of microbes and saprophages by hindering their metabolism (Chomel et al. 2016; Iqbal et al. 2012). The effects of PSM not only included decreases in the populations of decomposers but also alterations in their community structure, species diversity and ecological functions (Ushio et al. 2013; Zhou et al. 2013). In addition, PSM can lead to changes in soil enzymatic activities. For example, Joanisse et al. (2007) and Triebwasser et al. (2012) reported that tannins considerably inhibit the activities of soil glucosidase and peroxidase. Adamczyk et al.(2015) stated that monoterpenes and higher terpenes can suppress the activities of soil protease, acid phosphatase and chitinase. In addition, many investigations showed that PSM can affect the soil nutrient conditions and acid-base properties by influencing certain microbial groups and enzymes (Chomel et al. 2016). Because soil properties are the most important factors affecting the decomposition of leaf litter in certain climatic conditions, the mentioned changes in soil properties caused by the PSM released from one type of leaf litter would certainly affect the decomposition of other types of leaf litter in the mixture.

Many studies have concluded that PSM can accelerate or inhibit leaf litter decomposition and consequently affect the nutrient cycling of an ecosystem (Coq et al. 2010; Hättenschwiler \& Jørgensen 2010; Madritch et al. 2006). However, most of the existing studies have focused on the effects of endogenous, highly condensed PSM from leaf litter on their own decomposition process (Chomel et al. 2016). In contrast, the influences of the exogenetic, micromolecular PSM released by leaf litter on the decomposition of other leaf litter types involved in mixed-leaf litter decomposition are still unclear. In addition, in the studies that investigated the exogenetic PSM, there were generally only one or a few types of PSM that were used to treat receptor leaf litter; this is also quite different from natural conditions.

The Qinling Mountains are one of the most important distribution areas of forest resources in China, and mixed afforestation is the preferred approach for transforming natural forests and regenerating artificial forests. Thus, in this study, a typical tree species found in Qinling Mountain forests, Betula albo-sinensis, and five coniferous species that are often used to form mixed forests with $B$. albosinensis were investigated. B. albo-sinensis leaf litter and its decomposition medium (soil) were treated with the water extracts of coniferous leaf litter during a 6-month indoor experiment using mesocosms. The dynamics of mass loss, the nutrient (, , N, P and K) contents of leaf litter residue and the soil enzymatic activities were measured to investigate the effects of PSM from coniferous needle leaf litter on the leaf litter decomposition processes of $B$. albo-sinensis. The results may help clarify the roles of PSM on decomposition processes of mixed leaf litter, and they might also provide a scientific basis for choosing suitable tree species to form mixed forests with B. albo-sinensis.

\section{MATERIALS AND METHODS}

\section{STUDY AREA}

The materials used in this study were sampled from the Hozhenzi Forestry Station in Zhouzhi County, Shaanxi Province, China, which is located on the northern slope of Middle Qinling Mountain. The climate in this region is classified as warm-temperate humid climate, with an annual average temperature of $7.4^{\circ} \mathrm{C}$ and an annual average precipitation of $900 \mathrm{~mm}$. The altitude is 1500 to 2500 $\mathrm{m}$, and the soil is classified as Ustalf, according to USDA taxonomy. There are many natural secondary forests and plantations in this area, and B. albo-sinensis is one of the predominant forest types found here.

\section{LEAF LITTER AND SOIL SAMPLING AND TREATMENTS}

In the late autumn, mature forest stands of B. albo-sinensis and five coniferous species (Pinus tabuliformis, Platycladus orientalis, Pinus armandii, Larix principis-rupprechtii and Picea asperata) were selected in the study area, and the leaf litter (in this case, senescent leaves) of these species were sampled by placing leaf litter traps under 10 trees, mixing the collected samples, and preserving samples by allowing them to air dry. Specifically, B.albo-sinensis (BA) leaf litter was used for the decomposition experiments. The BA leaf litter was cut into $1.5 \mathrm{~cm}$ fragments, and $6 \mathrm{~g}$ of the fragments were placed into each nylon leaf litterbag of $0.5 \mathrm{~mm}$ mesh $(10 \mathrm{~cm} \times 20 \mathrm{~cm})$ and sealed. A total of 90 bags with leaf litter were prepared. The leaf litters from five types of coniferous species were used for obtaining leaf litter water extracts, which were then used to treat BA leaf litter and its decomposition medium (soil). In this study, water extraction was used to simulate the leaching processes that occur in natural conditions. Specifically, 
the coniferous leaf litter was cut into needles of $1.5 \mathrm{~cm}$ in length, and water extracts were obtained by soaking the cut needles in sterilised distilled water with a concentration of $80 \mathrm{mg} \mathrm{mL}^{-1}$ (i.e. $8 \mathrm{~g}$ of leaf litter was soaked in $100 \mathrm{~mL}$ of water) for $48 \mathrm{~h}$. After that, the mixtures were centrifuged and filtered, and then the filtrates were preserved in brown glass bottles at $4^{\circ} \mathrm{C}$. The concentration of the extracts was determined based on the average annual precipitation and the average annual total leaf litterfall of the five types of coniferous species.

To eliminate the impacts of forest soil on exogenous PSM, such as the PSM or enzymes secreted by B. albosinensis or special microflora, the soil used for this study was collected from the surface layer $(0$ to $10 \mathrm{~cm})$ of a plant-free wasteland near the study forests. After removing extra materials, such as roots and stones, the fresh soil was passed through a $5 \mathrm{~mm}$ sieve and sufficiently homogenised. The prepared soil was slightly air-dried to control for humidity in the following experiments, and then it was used as decomposition medium.

\section{LEAF LITTER DECOMPOSITION EXPERIMENTS}

For leaf litter decomposition experiments, a total of 0.95 $\mathrm{kg}$ of prepared soil medium was placed into a plastic pot. Five of the leaf litterbags containing BA leaf litter were separately buried in each pot. A total of 18 pots were prepared, and 15 of the pots were treated with five types of coniferous leaf litter extracts. To do this, $50 \mathrm{~mL}$ of extract from a specific type of leaf litter was uniformly sprayed into the soil in one pot, and $50 \mathrm{~mL}$ distilled water was sprayed on the remaining pot to be used as a control (CK). After the treatment, the soil moisture was approximately $60 \%$ of the field water holding capacity of soil. Hereafter, the pots were treated with $50 \mathrm{~mL}$ of leaf litter extracts or water twice per month, and the soil moisture was maintained at approximately constant levels (according to the results of preliminary experiments, the evaporation loss was measured at approximately $50 \mathrm{~mL}$ per pot during a 2 -week experimental period). The BA leaf litter was incubated in these conditions at the natural laboratory temperature (20 to $30^{\circ} \mathrm{C}$ ) for 6 months.

During the experiment, leaf litterbags were retrieved five times at the first, second, third, fifth and sixth month, respectively. Each time, one leaf litterbag was randomly retrieved from each pot, and the leaf litterbags sharing the same treatment were regarded as replicates. After retrieval, the leaf litter residues were placed in a $0.15 \mathrm{~mm}$ soil sieve, and the sundries in the leaf litter were carefully removed by sieving and brushing. The cleaned leaf litter residues were oven-dried to constant weight for the determination of mass and nutrient $(\mathrm{C}, \mathrm{N}, \mathrm{P}$ and $\mathrm{K})$ contents.

In addition, at the first, third and sixth month of decomposition, the soil medium was sampled to determine the activities of leaf litter-decomposing enzymes including sucrase, carboxymethyl cellulase, $\beta$-glucosidase, polyphenol oxidase, protease and acid phosphatase. During sampling, soil samples were collected from each pot sharing the same treatment to allow for replicate samples, and only a portion of the soil between the leaf litterbags was collected, ensuring the soil conditions around the leaf litter bags remained mostly undisturbed.

\section{DETERMINATION OF LEAF LITTER NUTRIENT CONTENTS AND SOIL ENZYMATIC ACTIVITIES}

For the reserved BA leaf litter and the decomposed residues, the following methods were used to determine the initial and remaining nutrient concentrations (Zhang et al. 2016). The $\mathrm{C}$ concentration was determined using the potassium dichromate oxidation method. The concentrations of $\mathrm{N}, \mathrm{P}$ and $\mathrm{K}$ were determined using a continuous-flow analytical system (AA3, Bran Luebbe, Germany), a UV-Vis spectrometer (UV-2450 Shimadzu Corporation, Kyoto, Japan), vanadium-molybdate-yellow colorimetry and a flame photometer (BMB Technologies UK Ltd.) after the leaf litter samples were digested by $\mathrm{H}_{2} \mathrm{SO}_{4}-\mathrm{H}_{2} \mathrm{O}_{2}$ mixture. The remaining nutrient concentrations were obtained by calculating the product of the concentration of each nutrient and the mass of leaf litter remaining.

The soil enzymatic activities were presented as the output (mg or mmol) of hydrolyd and oxydic products per gram of dry soil per day. The activities of sucrase and carboxymethyl cellulase were determined by 3,5-dinitrosalicylic acid colorimetry (the product was glucose, $\mathrm{mg}$ ), the activity of $\beta$-glucosidase was determined by nitrophenol colorimetry (nitrophenol, mmol), the activity of polyphenol oxidase was determined by pyrogallol colorimetry (pyrogallol, mg), the activity of protease was determined by ninhydrin colorimetry (amino nitrogen, $\mathrm{mg}$ ), and the activity of acid phosphatase was determined by disodium phenyl phosphate colorimetry (phosphorus pentoxide, mg) (Zhang et al. 2016).

\section{QUALITATIVE DETERMINATION OF PSM OF LEAF LITTER EXTRACTS}

According to our previous study (accepted data), the PSM in leaf litter extracts were detected using a gas chromatograph-mass spectrometer (GC-MS, GCMS-QP 2010 Ultra, Shimadzu, Tokyo), and the PSM found in five types of extracts were listed in Table S1.

\section{DATA PROCESSING}

The BA leaf litter decomposition processes in different treatments were simulated using a modified exponential decay model (1) using SigmaPlot 12.5 (Systat Software Inc., UK), and the turnover period (the time when the mass-loss rate was $95 \%, T_{0.95}$ ) and half-life period (the time when the mass-loss rate was $50 \%, T_{0.50}$ ) of leaf litter decomposition were also calculated using SigmaPlot 12.5.

$$
R=a \mathrm{e}^{-b t}+c \mathrm{e}^{-d t}
$$

where $R$ is the residual rate of decomposed leaf litter; $a$, $b, c$ and $d$ are the parameters of the model; and $t$ is the duration of decomposition (yr). 
In this approach, the $T_{0.95}$ and $T_{0.50}$ of BA leaf litter were calculated three times with the following statistical analyses, using the decomposition models obtained from 3 replications. The leaf litter decomposition processes were simulated using the mass-loss data (collected from 5 sampling events) from each pot sharing the same treatment. IBM SPSS 20.0 (SPSS, Chicago, IL, USA) was employed for the one-way analysis of variance, and the least significant difference method was used for the post hoc analysis $(\alpha=0.05)$. SigmaPlot 12.5 was used for drawing graphs.

\section{RESULTS}

\section{LEAF LITTER DECOMPOSITION}

The results indicated that the extracts of leaf litters from $P$. tabuliformis (PT), P. orientalis (PO), P. armandii (PA) and $L$. principis-rupprechtii $(\mathrm{LP})$ significantly $(p<0.05)$ extended the $T_{0.95}$ of the BA leaf litter decomposition by 4.77 times, 2.19 times, 1.24 times and 8.05 times, respectively (Table 1). These four types of extracts also significantly extended the $T_{0.50}$ of the BA leaf litter decomposition by 1.64 times, 1.13 times, 0.48 times and 5.25 times, respectively. Hence, PT, PO, PA and LP leaf litter extracts significantly inhibited the overall decomposition of the BA leaf litter, including both the early and late stages. Among these extracts, the LP leaf litter extracts exhibited the most significant inhibitory effects (especially on the early stage of decomposition), followed by the PT leaf litter extracts. In contrast, the inhibitory effects of the PO and PA leaf litter extracts were relatively weak. Finally, the P. asperata (PAs) leaf litter extracts exhibited no significant influence on the early or late decomposition of the BA leaf litter.

\section{RELEASE OF C, N, P AND K}

Similar to the results described previously, the PT, PO, PA and LP leaf litter extracts significantly hindered the overall nutrients released in the BAleaf litter, though the PAs leaf litter extracts exhibited approximately equal promoting and inhibitory effects (Figure 1). Specifically, at the end of decomposition experiment (6 months), the PT leaf litter extracts significantly inhibited the release of $\mathrm{C}$ and $\mathrm{P}$ in the BA leaf litter, the PO and LP leaf litter extracts significantly inhibited the release of $\mathrm{C}, \mathrm{N}, \mathrm{P}$ and $\mathrm{K}$, the PA leaf litter extracts significantly inhibited the release of $\mathrm{C}, \mathrm{P}$ and $\mathrm{K}$, while simultaneously accelerating the release of $\mathrm{N}$, and the PAs leaf litter extracts significantly inhibited the release of $\mathrm{K}$, while simultaneously accelerating the release of $\mathrm{N}$ and $\mathrm{P}$.

In this experiment, the effects of all types of leaf litter extracts on the release of the four measured nutrients in BA leaf litter were irregular, especially during months 1 to 3 (Figure 1), the effects of the same treatment on a given element generally resulted in a sudden conversion. However, in general, the PT leaf litter extracts exhibited inhibitory effects on the overall nutrients $(\mathrm{C}, \mathrm{N}, \mathrm{P}$ and $\mathrm{K})$ released in the $\mathrm{BA}$ leaf litter throughout the entire experiment. The PO, PA and LP treatments mainly exhibited accelerating effects (especially on the release of $\mathrm{P}$ and $\mathrm{K}$ ) during the first month, but then switched to having inhibitory effects. In contrast to other treatments, the PAs leaf litter extracts exhibited considerable inhibitory effects from the first to the fifth month, and then it suddenly switched to having accelerating effects at the end of the decomposition experiment.

\section{DYNAMICS OF ENZYMATIC ACTIVITIES}

After being treated with coniferous leaf litter extracts, the soil enzymatic activities were significantly altered (Figure 2). The PT, PO, PA and LP leaf litter extracts exhibited similar effects on the enzymes that participate in the $C$ and $P$ release in leaf litter. Among them, the activity of sucrase (which mainly participates in the early decomposition of leaf litter) was generally inhibited at the first or the third month of the decomposition experiment. Meanwhile, the activities of carboxymethyl cellulase and $\beta$-glucosidase (middle stage) were inhibited during the third to sixth months, the activity of polyphenol oxidase (early and late stages) was significantly accelerated at the first and the sixth month and inhibited at the third month, and the activity of phosphatase was inhibited at the first month but generally accelerated thereafter. For soil protease, its activity was significantly accelerated by the PT and PA extracts and inhibited by the PO and LP extracts.

However, during decomposition, the PAs extract generally exhibited various effects on the enzymes that participate in the release of $\mathrm{C}$ in leaf litter. For example, the effects of the PAs extracts on sucrase activity changed from significant inhibition to acceleration between the

TABLE 1. The turnover period and half-life period of B. albo-sinensis leaf litter decomposition in different treatments

\begin{tabular}{lccc}
\hline Extracts (treatments) & Decomposition models & Turnover period $T_{0.95}(\mathrm{yr})$ & Half-life period $T_{0.50}(\mathrm{yr})$ \\
\hline P. tabuliformis & $\mathrm{R}=0.3587 \mathrm{e}^{-6.7003 \mathrm{t}}+0.6572 \mathrm{e}^{-0.1393 \mathrm{t}}$ & $25.96(0.13) \mathrm{b}^{1}$ & $2.30(0.21) \mathrm{b}$ \\
P. orientalis & $\mathrm{R}=0.2920 \mathrm{e}^{-11.5713 \mathrm{t}}+0.7142 \mathrm{e}^{-0.2156 \mathrm{t}}$ & $14.36(0.62) \mathrm{c}$ & $1.85(0.32) \mathrm{b}$ \\
P. armandii & $\mathrm{R}=0.3364 \mathrm{e}^{-11.8701 \mathrm{t}}+0.6638 \mathrm{e}^{-0.2371 \mathrm{t}}$ & $10.07(0.12) \mathrm{c}$ & $1.29(0.06) \mathrm{b}$ \\
L. principis-rupprechtii & $\mathrm{R}=0.3336 \mathrm{e}^{-6.9519 \mathrm{t}}+0.6874 \mathrm{e}^{-0.0575 \mathrm{t}}$ & $40.73(4.64) \mathrm{a}$ & $5.44(0.75) \mathrm{a}$ \\
P. asperata & $\mathrm{R}=0.1776 \mathrm{e}^{-11.1086 \mathrm{t}}+0.8349 \mathrm{e}^{-1.0260 \mathrm{t}}$ & $2.87(0.27) \mathrm{de}$ & $0.50(0.02) \mathrm{c}$ \\
Water $(\mathrm{CK})$ & $\mathrm{R}=0.1254 \mathrm{e}^{-46.3443 \mathrm{t}}+0.8746 \mathrm{e}^{-0.6683 \mathrm{t}}$ & $4.50(0.48) \mathrm{d}$ & $0.87(0.07) \mathrm{c}$ \\
\hline
\end{tabular}

${ }^{1}$ Note: The data were average (SE), and the different letters in the same column indicate significant differences among treatments 

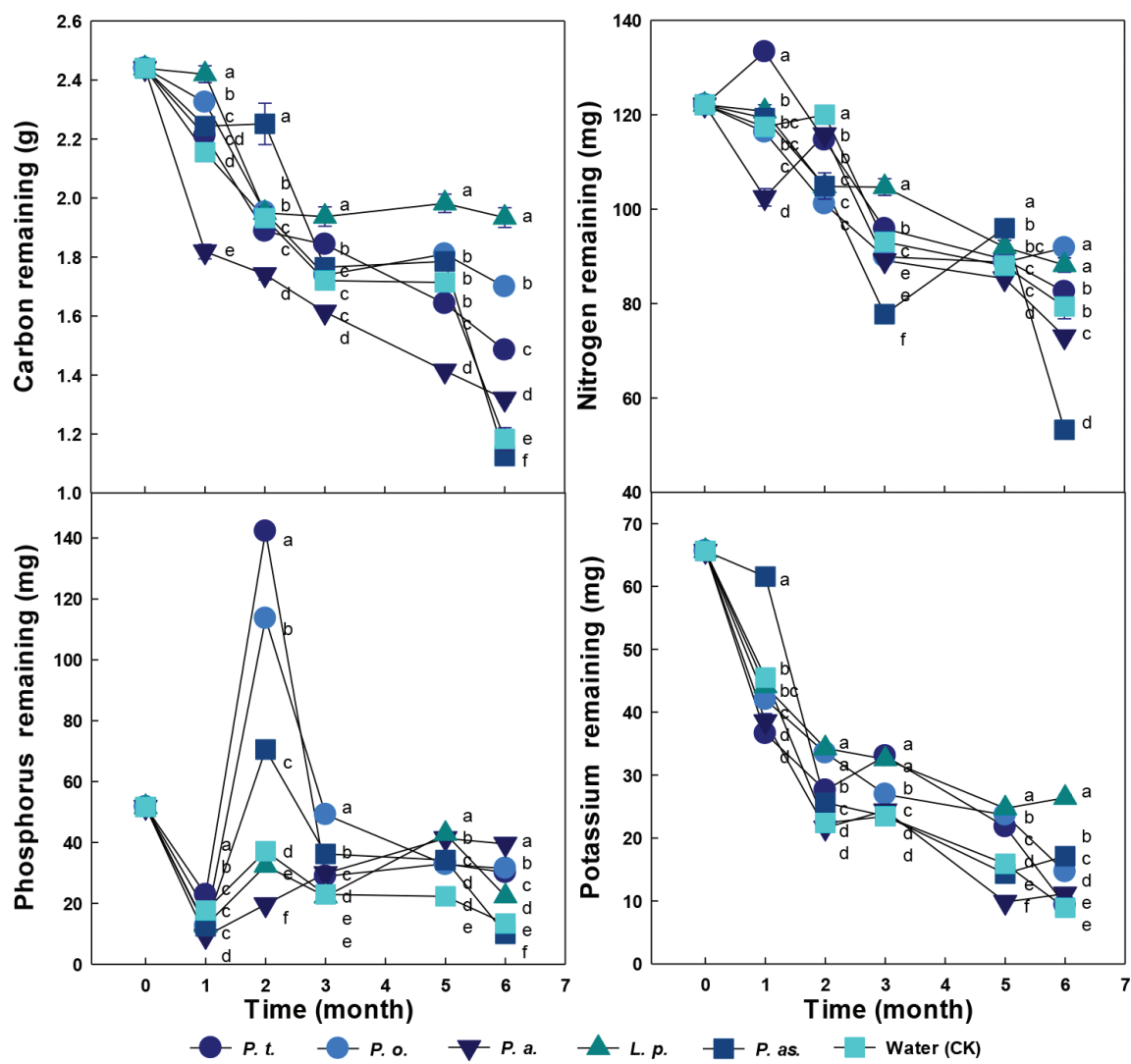

FIGURE 1. The nutrients released during the decomposition of $B$. albo-sinensis leaf litter

The data are presented as average (SE), and the different letters in the same column indicate significant differences among treatments. P.t.-P. tabuliformis; P. o.-P. orientalis; P. a.-P. armandii; L. p.-L. principis-rupprechtii; P. as.-P. asperata

first and the third months, respectively. Its effects on carboxymethyl cellulase and $\beta$-glucosidase changed from acceleration to inhibition between the third and sixth months. Additionally, its effects on polyphenol oxidase changed from acceleration to inhibition between the first and the third months. However, the PAs extract generally

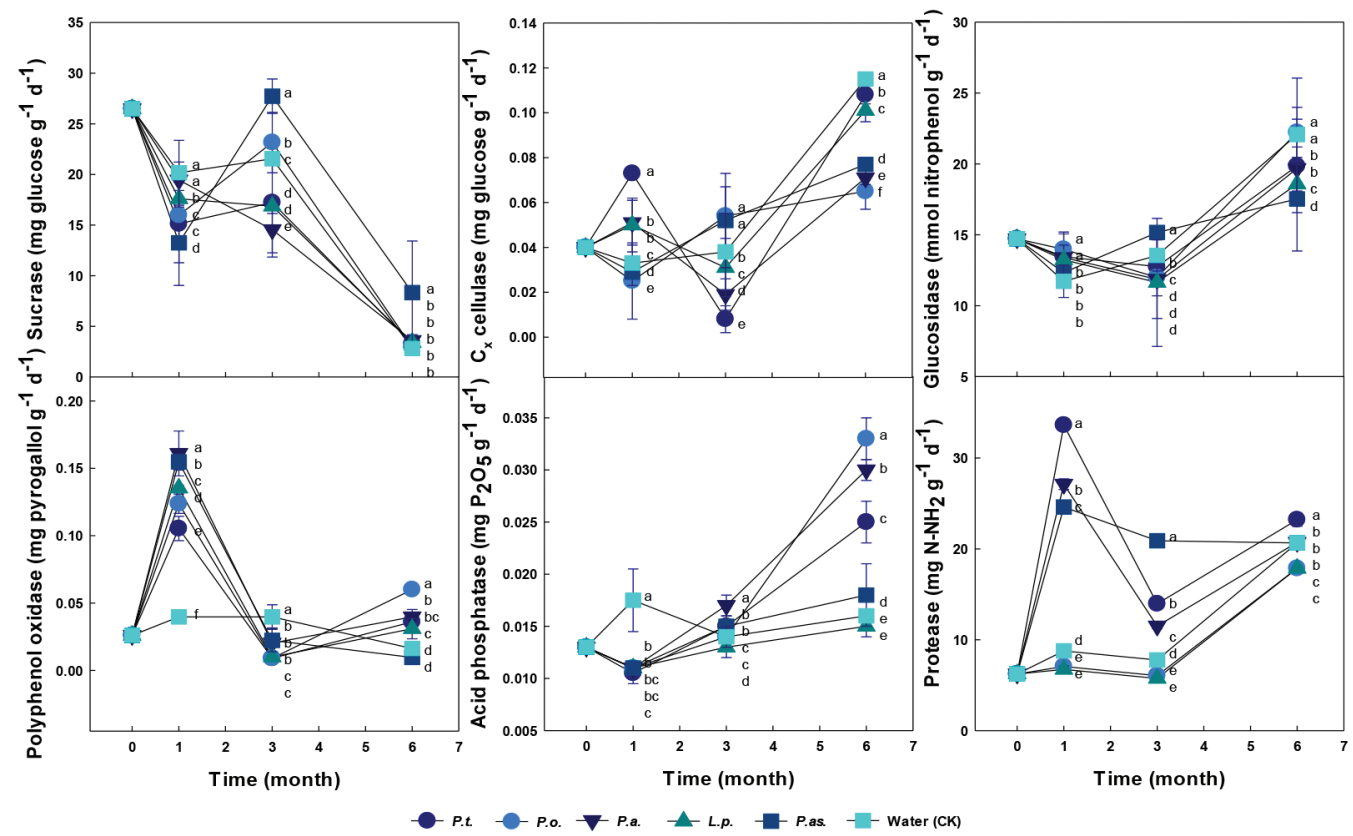

FIGURE 2. Dynamics of soil enzymatic activities during the decomposition of B. albo-sinensis leaf litter 
accelerated the activities of acid phosphatase and protease during the decomposition experiment.

\section{DISCUSSION}

\section{DECOMPOSITION RATE OF B. ALBO-SINENSIS LEAF LITTER}

The results indicated that the extracts of PT, PO, PA, and LP leaf litters significantly inhibited the decomposition of BA leaf litter which are in line with the findings of previous work (Coq et al. 2010; Hättenschwiler \& Jørgensen 2010; Madritch et al. 2006), which state that PSM will inhibit leaf litter decomposition. The reason for these results might be the presence of terpenes, phenolic and steroid compounds in the leaf litter extracts (Table S1), which inhibit the activities of leaf litter-decomposing enzymes by creating complexes with them (Adamczyk et al. 2013; Triebwasser et al. 2012). For instance, Li et al. (2016a) reported that cinnamic acid, which was found in LP extracts (Table S1, though, in the following text, only tree species were given), can significantly suppress the activities of soil sucrase and phosphatase. $\beta$-myrcene (PT, Table S1), pinene (all species, Table S1), abietic acid (PA, Table S1) and $\beta$-sitosterol (PT, PO, PA and LP, Table S1) can significantly inhibit the activities of soil protease, $\beta$-glucosidase, acid phosphatase and chitinase (Adamczyk et al. 2015). Dibutyl phthalate (PT, PO, LP and PAs, Table S1), in high concentrations, might considerably reduce the activities of acid phosphatase, sucrase and protease (Wang et al. 2015). In addition, PSM contained in the coniferous leaf litter extracts might also indirectly influence the soil enzymatic activities by affecting soil microbes which in turn has inhibitory effects on leaf litter decomposition. For example, the results of Li et al. (2016a) demonstrated that phenolic compounds can alter the proportion of intracellular and extracellular enzymes, which resulted in decreased soil enzymatic activity. Liu et al. (2012) reported that palmitic acid and stearic acid (PO, Table S1) will decrease the soil $\mathrm{pH}$ and alter the conformation of enzymes (Joanisse et al. 2007), thus, leading to decreases in soil sucrase and phosphatase. In studies by Zhang et al. (2013) and Zheng (2008), it was shown that phellandrene and camphene (PT, Table S1) inhibit the growth of Trichoderma spp., which might decrease the activities of cellulase (Naseby et al. 2000). In this study, activities of soil sucrase, carboxymethyl cellulase and $\beta$-glucosidase were significantly reduced after the soil was treated with the PT, PO, PA, and LP extracts, which are supported by the abovementioned literature. Since sucrase, carboxymethyl cellulase and $\beta$-glucosidase play critical roles in the early and intermediate stages of leaf litter decomposition, a decrease in their activity would certainly result in inhibitory effects on the early decomposition of BA leaf litter. It was noteworthy that, in these treatments, the activity of polyphenol oxidase (which mainly participates in the early and late stages of leaf litter decomposition) was significantly accelerated in the first and sixth month, which contrasted with the fact that the decomposition of the BA leaf litter was inhibited. It was speculated that the increase in the activity of polyphenol oxidase might be caused by the presence of phenolic PSM compounds and the adaptation of soil microbes to them (Wang et al. 2014). Thus, the increase in polyphenol oxidase activity might only have a small contribution on the decomposition of the BA leaf litter.

In addition to having direct or indirect effects on soil enzymes, PSM can also affect decomposers, which directly control the decomposition of leaf litter. For example, Chomel et al. (2016) summarised multiple studies and stated that phenolic and terpene compounds exhibited toxic effects on springtails and Collembola. Chen et al. (2013) found that camphor (PT and PAs, Table S1) exhibited obvious insecticidal efficacy. Consequently, PSM in leaf litter extracts might inhibit the early decomposition of leaf litter, and because of their effects on soil, animals might hinder the physical breakdown of leaf litter. In addition, PSM would also remarkably affect the soil microbes, which have critical roles in the complete decomposition of leaf litter, by hindering their physiological activity, decreasing their populations and biomass (Uusitalo et al. 2008) and influencing their adhesion, colonisation and hyphal growth, which all have important effects on leaf litter decomposition (Mierziak et al. 2014; Ormeno et al. 2006;). For example, pinene (all species, Table S1) can destroy the microbial cells, inhibit the breathing of microbes, inhibit ion transportation in microbes, or increase the membrane permeability of microbes (Cox et al. 2000). Dibutyl phthalate (PT, PO, LP and PAs, Table S1) can considerably inhibit the growth of filamentous fungi (Roy et al. 2006), $\beta$-sitosterol (PT, PO, PA and LP, Table $\mathrm{S} 1$ ), camphene (PT, Table S1) and borneol (PT, Table S1) can inhibit the spore development and hyphal growth of Aspergillus niger (Aderiye et al. 1989; Shi et al. 2015; Zheng 2008), and camphor and borneol (PT, Table S1) can inhibit the growth of Bacillus (Chen et al. 2013) and Mucor racemosus (Shi et al. 2015); all of which participate in leaf litter decomposition processes. Furthermore, PSM can also alter the community structure, species diversity and functional characteristics of soil microbes (Asensio et al. 2012). For instance, Adamczyk et al. (2013) and Zhou et al. (2010) indicated that abietic acid and palmitic acid (PO, Table S1) can significantly inhibit the growth of fungi, while simultaneously promoting the growth of bacteria (including actinomycetes). Li et al. (2014) reported that benzoic acid (PA, LP and PAs, Table S1) and palmitic acid (PO, Table S1) significantly decrease the genetic diversity of soil microbes. Since complete decomposition primarily depends on microbial activities, and it requires the synergistic effects caused by a variety of microbial species (Osono 2007), any changes in microbial populations, activities, species diversity and carbon utilisation can certainly hinder the entire leaf litter decomposition process. This might be the main reason explaining the observed inhibitory effects of leaf litter extracts (PT, PO, PA, and LP) on both early and late decomposition of BA leaf litter.

However, in the extracts of PAs leaf litter, a variety of PSM that exhibited inhibitory effects on soil enzymes 
and decomposers were also detected. Nevertheless, this extract did not exhibit obvious inhibitory effects on early or late decomposition of the BA leaf litter. The differences in PSM concentrations in the five types of leaf litter extracts might explain this phenomenon, as the effects of different PSM generally depend on their concentrations. For instance, the observed inhibitory effects of $\beta$-myrcene (PT) (Table S1), pinene (all species) (Table S1), abietic acid (PA) (Table S1) and $\beta$-sitosterol (PT, PO, PA and LP) (Table S1) on protease and $\beta$-glucosidase (Adamczyk et al. 2015), as well as the inhibitory effects of dibutyl phthalate (PT, PO, LP and Pas) (Table S1) (Wang et al. 2015), palmitic acid and stearic acid (PO) (Table S1) (Liu et al. 2012) on sucrase, were all dependent on their concentrations; their inhibitory effects were sometimes insignificant or even switched to accelerating effects at low concentrations (Liu et al. 2012). In this study, the increase in sucrase activity during some periods (Figure 2) of the treatment with PAs leaf litter extracts might be caused by concentration-dependent effects. Second, PSM usually exhibited dual accelerating/inhibitory effects, and they might also be utilised by microbes as carbon sources which would accelerate microbial growth and increase the activities of leaf litter-decomposing enzymes. For example, 4'-hydroxyacetophenone (PAs, Table S1) can be utilised by Pseudomonas spp. (Enguita \& Leitão 2013) and promote their growth which in turn might accelerate the activities of soil cellulase and xylanase. Acetovanillone (Pas) (Table S1) can provide a REDOX medium and accelerate the activity of laccase (Cañas et al. 2007), which is of great importance in the decomposition of lignin. The abovementioned factors might explain why extracts from PAs leaf litter (which contains a variety of PSM) exhibited no significant effect on the BA leaf litter decomposition.

\section{NUTRIENT RELEASES IN B. albo-sinensis LEAF LITTER}

The results indicated that the effects of coniferous leaf litter extracts on the nutrients released in BA leaf litter were similar to their effects on decomposition; that is, the PT, PO, PA, and LP leaf litter extracts significantly inhibited the overall nutrients released in the BA leaf litter, which agrees with the findings of Schweitzer et al. (2004), while PAs leaf litter extracts exhibited approximately equal inhibitory/accelerating effects on the nutrients released in the BA leaf litter.

Among them, the PT, PO, PA and LP leaf litter extracts significantly inhibited the $\mathrm{C}$ released in the BA leaf litter at the end of decomposition experiment, which might be attributed to their inhibitory effects on the C-releasing related enzymes (Figure 2), such as carboxymethyl cellulase and $\beta$-glucosidase. Decreases in these enzymes would certainly hinder the decomposition of cellulose, the main component of plant leaf litter, and, as a result, inhibit the C-release process. In addition, a previous study demonstrated that PSM can significantly decrease the populations and $\mathrm{C}$ metabolism capacity of soil microbes (Li et al. 2014), which ultimately decreases the rate of C loss in leaf litter. The previously mentioned four types of extracts also significantly inhibited the Prelease in BA leaf litter. However, only the treatment with LP extracts decreased the soil phosphatase activity, which was similar to the findings of Adamczyk et al. (2015) and Joanisse et al. (2007), while the other three treatments exhibited considerable accelerating effects on phosphatase activity during the decomposition experiment. It was speculated that the tannin compounds in the leaf litter extracts increased the activity of phosphatase by modifying its conformation (Adamczyk et al. 2017). In addition, the other PSMs in PT, PO, and PA leaf litter extracts might force microbes to secrete more phosphatase to obtain more phosphorus, which would allow them to decompose toxic PSM (such as synthesizing ATP to obtain energy and synthesizing nucleic acid to translate PSM-decomposing enzymes). However, the obtained P was used preferentially for the metabolism of microbes colonised on leaf litter, rather than released into soil (Schimel \& Hättenschwiler 2007), thus, the rates of P release decreased. Certainly, further research is still needed to verify this assumption. For N, the PO and LP extracts significantly inhibited its release. This might have resulted from the continuous inhibitory effects of PSM on protease activity, which was supported by the findings of Joanisse et al. (2007). In contrast, the treatment with PAs leaf litter extracts caused a significant increase in the soil protease activity during the first to third months of decomposition, which could be what caused the increase in the release rate of $\mathrm{N}$ in the BA leaf litter. In addition, PO, PA and LP significantly inhibited the release of $\mathrm{K}$ in the BA leaf litter, which could be attributed to the inhibitory effects these extracts have on the decomposition of BA leaf litter which could hinder the leaching of K. However, due to the differences in chemical compounds found among the extracts, it was speculated that the destruction of leaf litter structure under the treatment with the PO extracts was more severe than those in the treatments with the PA and LP extracts; hence the release of K was not hindered. Different from the treatments with the PT, PO, PA and LP extracts, the PAs extracts did not affect the decomposition of the BA leaf litter, though it significantly accelerated the release of $\mathrm{N}$ and $\mathrm{P}$, and this might be attributed to the stimulation of PSM, soil protease and phosphatase (Figure 2).

It was noteworthy that, during the early and intermediate stages of the decomposition experiment, the effects of applying the continuous leaf litter extracts on the release of the four evaluated elements exhibited frequent changes between inhibition and acceleration. For example, both the PT and PA extracts exhibited a pattern of 'inhibitory, no effect, inhibitory' on $\mathrm{N}$ and $\mathrm{K}$ releases. The short-term fluctuations and irregular alterations caused by the PSM on microbial and enzymatic properties might be regarded as the main drivers explaining the previously mentioned phenomena. Due to the toxicity and various chemical structures exhibited by PSM, a specific type of PSM should be used to evaluate its use/decomposition by only one or several microbial groups in soil (Ushio et al. 2013). 
TABLE S1. Plant secondary metabolites in the extracts of the 5 types of conifers needle leaf litter (qualitative analysis, DOI: 10.1007/s11676-018-0766-7)

\begin{tabular}{|c|c|}
\hline Leaf litter extracts & Plant secondary metabolites \\
\hline P. tabuliformis & $\begin{array}{l}12 \text { Terpenoids [(e)-linalool oxide; d-camphor; } 1(-) \text {-borneol; } 2,5 \text {-dioxocamphan; campholenic aldehyde; } \\
\text { camphene; bornyl acetate; } \beta \text {-myrcene; terpineol; phellandrene; } \alpha \text {-pinene; } \beta \text {-pinene]; } 3 \text { Phenolic compounds } \\
\text { [dibutyl phthalate; ferulic acid; caffeic acid]; } 1 \text { Steroid derivative }[\beta \text {-sitosterol] }\end{array}$ \\
\hline P. orientalis & $\begin{array}{l}6 \text { Terpenoids [ } \alpha \text {-thujone; caryphyllene; } \alpha \text {-pinene; } \beta \text {-pinene; thujene; caryophyllene]; } 2 \text { Phenolic } \\
\text { compounds [2,6-bis-4-methylphenol; dibutyl phthalate]; } 3 \text { Steroid derivatives [ } \beta \text {-sitosterol; cholesterol } \\
\text { isobutyl carbonate; cholesta-3,5-diene]; } 5 \text { Aliphatic acids [palmitic acid; stearic acid; oleic acid; linoleic } \\
\text { acid; capric acid] }\end{array}$ \\
\hline P. armandii & $\begin{array}{l}9 \text { Terpenoids [viridiflorol; (-)-oplopanone; 1-hydroxy-4-keto-2-ionone; isolongifolan- } 8 \text {-ol; } \\
\text { sandaracopimaric acid; isodextropimaric acid; abietic acid; } \alpha \text {-pinene; } \beta \text {-pinene]; } 2 \text { Phenolic compounds } \\
\text { [benzoic acid; dibutyl phthalate]; } 1 \text { Steroid derivative }[\beta \text {-sitosterol] }\end{array}$ \\
\hline L. principis-rupprechtii & $\begin{array}{l}5 \text { Terpenoids [3,7,11,15-tetramethyl-2-hexadecen-1-ol; caryophyllene; cadinol; } \alpha \text {-pinene; } \beta \text {-pinene]; } 6 \\
\text { Phenolic compounds [2,4-bis(1-methyl-1-phenylethyl)-phenol; ferulic acid; caffeic acid; cinnamic acid; } \\
\text { phenylacetic acid; benzoic acid]; } 7 \text { Steroid derivatives [ } \gamma \text {-sitosterol; } \beta \text {-sitosterol; cholesteryl chloroformate; } \\
\text { cyclolaudenol; stigmast-5-en-3-ol; oleate double; stigmasterol acetate]; } 1 \text { Aliphatic acid [9,12-linoleic acid] }\end{array}$ \\
\hline P. asperata & $\begin{array}{l}7 \text { Terpenoids [(-)-camphor; isoborneol; } \alpha \text {-dihydroterpineol; aromadendrene oxide-(1); spathulenol; } \\
\alpha \text {-pinene; } \beta \text {-pinene]; } 5 \text { Phenolic compounds [benzoic acid; 4'-hydroxyacetophenone; acetovanillone; } \\
\text { o-acetylphenol; dibutyl phthalate]; } 1 \text { other PSM [(7z)-7-hexadecenal] }\end{array}$ \\
\hline
\end{tabular}

The decomposition or combinations of these PSM in soil might increase the complexity of their effects (Zhang et al. 2015) and lead to continuous changes in their effects, such as toxicity, growth stimulation and 'environmental stress screening' (Mierziak et al. 2014; Ushio et al. 2013). Thus, the soil biological conditions might be disturbed in the short term, which results in changes in the effects of different leaf litter extracts on the nutrients released in BA leaf litter. Certainly, after long-term treatments with different extracts, soil decomposers and enzymatic properties would adapt to the new environmental conditions, and the effects of each type of leaf litter extract would tend to stabilize and exhibit long-term inhibitory or accelerating effects.

\section{CONCLUSION}

The leaf litter extracts of $P$. tabuliformis, $P$. orientalis, $P$. armandii and $L$. principis-rupprechtii were found to significantly inhibit the whole decomposition process and overall nutrients release of B. albo-sinensis leaf litter. Meanwhile, the extracts of $P$. asperata leaf litter exhibited no significant influence on the process. The inhibitory effects of the extracts of $P$. tabuliformis, $P$. orientalis, $P$. armandii and L. principis-rupprechtii leaf litter might be due to the general suppression of PSM on the soil sucrase, carboxymethyl cellulase and $\beta$-glucosidase activities. In conclusion, these species causing inhibitory effects were not recommended to be planted with B. albo-sinensis, or the mixed forests should contain lower planting density of these coniferous species.

\section{ACKNOWLEDGEMENTS}

The authors thank Dr. Jiyuan Xu and Yupeng Lu for their help with the experiments. This research was funded by the National Natural Science Foundation of China (31800370), the Natural Science Basic Research Plan in Shaanxi Province of China (2018JQ4047), the Young Talent fund of University Association for Science and Technology in Shaanxi, China (20170704), and the Specialized Research Fund for the Doctoral Program of Yan'an University (YDBK2017-26) and College Students Innovation and Entrepreneurship Training Program (D2017082; D2017076).

\section{REFERENCES}

Adamczyk, B., Karonen, M., Adamczyk, S., Engström, M.T., Laakso, T., Saranpää, P., Kitunen, V., Smolander, A. \& Simon, J. 2017. Tannins can slow-down but also speed-up soil enzymatic activity in boreal forest. Soil Biology and Biochemistry 89: 60-67.

Adamczyk, S., Adamczyk, B., Kitunen, V. \& Smolander, A. 2015. Monoterpenes and higher terpenes may inhibit enzyme activities in boreal forest soil. Soil Biology and Biochemistry 87: 59-66.

Adamczyk, S., Kiikkilä, O., Kitunen, V. \& Smolander, A. 2013. Potential response of soil processes to diterpenes, triterpenes and tannins: Nitrification, growth of microorganisms and precipitation of proteins. Applied Soil Ecology 67: 47-52.

Aderiye, B.I., Ogundana, S.K., Adesanya, S.A. \& Roberts, M.F. 1989. The effect of $\beta$-sitosterol on spore germination and germ-tube elongation of Aspergillus niger and Botryodiplodia theobromae. International Journal of Food Microbiology 8(1): 73-78

Asensio, D., Yuste, J.C., Mattana, S., Ribas, À., Llusià, J. \& Peñuelas, J. 2012. Leaf litter VOCs induce changes in soil microbial biomass $\mathrm{C}$ and $\mathrm{N}$ and largely increase soil $\mathrm{CO}_{2}$ efflux. Plant and Soil 360(1-2): 163-174.

Cañas, A.I., Alcalde, M., Plou, F., Martínez, M.J., Martínez, Á.T. \& Camarero, S. 2007. Transformation of polycyclic aromatic hydrocarbons by laccase is strongly enhanced by 
phenolic compounds present in soil. Environmental Science \& Technology 41(8): 2964-2971.

Chapman, S.K., Newman, G.S., Hart, S.C., Schweitzer, J.A. \& Koch, G.W. 2013. Leaf litter mixtures alter microbial community development: Mechanisms for non-additive effects in leaf litter decomposition. PloS ONE 8(4): e62671.

Chen, W., Vermaak, I. \& Viljoen, A. 2013. Camphor-a fumigant during the black death and a coveted fragrant wood in ancient Egypt and Babylon-a review. Molecules (Basel, Switzerland) 18(5): 5434-5454.

Chomel, M., Guittonny-Larchevêque, M., Fernandez, C., Gallet, C., DesRochers, A., Paré, D., Jackson, B.G. \& Baldy, V. 2016. Plant secondary metabolites: A key driver of litter decomposition and soil nutrient cycling. Journal of Ecology 104(6): 1527-1541.

Coq, S., Souquet, J.M., Meudec, E., Cheynier, V. \& Hättenschwiler, S. 2010. Interspecific variation in litter tannins drives decomposition in a tropical rain forest of French Guiana. Ecology 91(7): 2080-2091.

Cox, S., Mann, C., Markham, J., Bell, H., Gustafson, J., Warmington, J. \& Wyllie, S. 2000. The mode of antimicrobial action of the essential oil of Melaleuca alternifolia (tea tree oil). Journal of Applied Microbiology 88(1): 170-175.

De Marco, A., Meola, A., Maisto, G., Giordano, M. \& De Santo, A.V. 2011. Non-additive effects of leaf litter mixtures on decomposition of leaf litters in a Mediterranean maquis. Plant and Soil 344(1-2): 305-317.

Duan, J., Wang, S., Zhang, Z., Xu, G., Luo, C., Chang, X., Zhu, X., Cui, S., Zhao, X. \& Wang, W. 2013. Non-additive effect of species diversity and temperature sensitivity of mixed litter decomposition in the alpine meadow on Tibetan Plateau. Soil Biology and Biochemistry 57: 841-847.

Enguita,F.J. \& Leitão,A.L. 2013. Hydroquinone: Environmental pollution, toxicity, and microbial answers. BioMed Research International 2013: e542168.

Gartner, T.B. \& Cardon, Z.G. 2004. Decomposition dynamics in mixed-species leaf litter. Oikos 104(2): 230-246.

Ghasemi-Aghbash, F., Hosseini, V. \& Poureza, M. 2015. Nutrient dynamics and early decomposition rates of Picea abies needles in combination with Fagus orientalis leaf litter in an exogenous ecosystem. Annals of Forest Research 59(1): 21-32.

Hättenschwiler, S. \& Jørgensen, H.B. 2010. Carbon quality rather than stoichiometry controls litter decomposition in a tropical rain forest. Journal of Ecology 98(4): 754-763.

Hättenschwiler, S., Tiunov, A.V. \& Scheu, S. 2005. Biodiversity and litter decomposition in terrestrial ecosystems. Annual Review of Ecology, Evolution, and Systematics 36: 191-218.

Iqbal, J., Siegrist, J.A., Nelson, J.A. \& McCulley, R.L. 2012. Fungal endophyte infection increases carbon sequestration potential of southeastern USA tall fescue stands. Soil Biology and Biochemistry 44(1): 81-92.

Joanisse, G., Bradley, R., Preston, C. \& Munson, A. 2007. Soil enzyme inhibition by condensed litter tannins may drive ecosystem structure and processes: The case of Kalmia angustifolia. New Phytologist 175(3): 535-546.

Li, Q. \& Liu, Z. 2013. Effects of decomposed leaf litter mixtures from Platycladus orientalis and broadleaf tree species on soil properties. Scandinavian Journal of Forest Research 28(7): 642-650.

Li, Q., Liu, P., Tang, Z., Zhao, H., Wang, J., Song, X., Yang, L. \& Wan, S. 2016a. Effects of two phenolic acids on root zone soil nutrients, soil enzyme activities and pod yield of peanut. Chinese Journal of Applied Ecology 27(4): 1189-1195.
Li, Q., Zhao, G., Cao, G. \& Liu, Z. 2016b. Soil effects of six different two-species litter mixtures that include Ulmus pumila. Chemistry and Ecology 32(8): 707-721.

Li, Y., Ying, Y.X., Zhao, D.Y. \& Ding, W.L. 2014. Influence of allelochemicals on microbial community in ginseng cultivating soil. Chinese Herbal Medicines 6(4): 313-318.

Liu, P., Huang, J., Sun, O.J. \& Han, X. 2010. Litter decomposition and nutrient release as affected by soil nitrogen availability and litter quality in a semiarid grassland ecosystem. Oecologia 162(3): 771-780.

Liu, P., Liu, Z., Wang, C., Guo, F., Wang, M., Zhang, Y., Dong, L. \& Wan, S. 2012. Effects of three long-chain fatty acids present in peanut (Arachis hypogaea L.) root exudates on its own growth and the soil enzymes activities. Allelopathy Journal 29(1): 13-24.

Madritch, M., Donaldson, J.R. \& Lindroth, R.L. 2006. Genetic identity of Populus tremuloides litter influences decomposition and nutrient release in a mixed forest stand. Ecosystems 9(4): 528-537.

Mao, B., Yu, Z.Y. \& Zeng, D.H. 2015. Non-additive effects of species mixing on litter mass loss and chemical properties in a Mongolian pine plantation of Northeast China. Plant and Soil 396(1-2): 339-351.

Mierziak, J., Kostyn, K. \& Kulma, A. 2014. Flavonoids as important molecules of plant interactions with the environment. Molecules (Basel, Switzerland) 19(10): 1624016265.

Naseby, D., Pascual, J. \& Lynch, J. 2000. Effect of biocontrol strains of Trichoderma on plant growth, Pythium ultimum populations, soil microbial communities and soil enzyme activities. Journal of Applied Microbiology 88(1): 161-169.

Ormeno, E., Baldy, V., Ballini, C., Larchevêque, M., Périssol, C. \& Fernandez, C. 2006. Effects of environmental factors and leaf chemistry on leaf litter colonization by fungi in a Mediterranean shrubland. Pedobiologia 50(1): 1-10.

Osono, T. 2007. Ecology of ligninolytic fungi associated with leaf litter decomposition. Ecological Research 22(6): 955-974.

Purahong, W., Kapturska, D., Pecyna, M.J., Schulz, E., Schloter, M., Buscot, F., Hofrichter, M. \& Krüger, D. 2014. Influence of different forest system management practices on leaf litter decomposition rates, nutrient dynamics and the activity of ligninolytic enzymes: A case study from Central European forests. PloS ONE 9(4): e93700.

Roy, R., Laskar, S. \& Sen, S. 2006. Dibutyl phthalate, the bioactive compound produced by Streptomyces albidoflavus 321.2. Microbiological Research 161(2): 121-126.

Schimel, J.P. \& Hättenschwiler, S. 2007. Nitrogen transfer between decomposing leaves of different N status. Soil Biology and Biochemistry 39(7): 1428-1436.

Schweitzer, J.A., Bailey, J.K., Rehill, B.J., Martinsen, G.D., Hart, S.C., Lindroth, R.L., Keim, P. \& Whitham, T.G. 2004. Genetically based trait in a dominant tree affects ecosystem processes. Ecology Letters 7(2): 127-134.

Shi, B., Luan, D., Wang, S., Zhao, L., Tao, L., Yuan, Q. \& Wang, X. 2015. Borneol-grafted cellulose for antifungal adhesion and fungal growth inhibition. RSC Advances 5: 51947-51952.

Triebwasser, D.J., Tharayil, N., Preston, C.M. \& Gerard, P.D. 2012. The susceptibility of soil enzymes to inhibition by leaf litter tannins is dependent on the tannin chemistry, enzyme class and vegetation history. New Phytologist 196(4): 11221132 .

Ushio, M., Balser, T.C. \& Kitayama, K. 2013. Effects of condensed tannins in conifer leaves on the composition and 
activity of the soil microbial community in a tropical montane forest. Plant and Soil 365(1-2): 157-170.

Uusitalo, M., Kitunen, V. \& Smolander, A. 2008. Response of $\mathrm{C}$ and $\mathrm{N}$ transformations in birch soil to coniferous resin volatiles. Soil Biology and Biochemistry 40(10): 2643-2649.

Wang, J., Wang, D., Yu, F., Shen, W., Zou, C., Zhang, R. \& Hou, P. 2014. Enzyme activity in rhizosphere soil of Cryptomeria fortunei seedlings with simulated acid rain and litter. Journal of Zhejiang Forestry College 31(3): 373-379.

Wang, Z., Zhao, X., Xu, W., Su, Y., You, Y., Liu, S., Hu, Y., Yang, Y. \& Zhang, Y. 2015. Response of microbial biomass and enzyme activities in black soil to din-butyl phthalate contamination. Asian Journal of Ecotoxicology 10(6): 199205.

Zhang, F., Guo, A., Li, Q., Li, H., Hu, M. \& Wang, F. 2013. The allelopathic effects of five volatiles released from Eupatorium adenophora on Trichoderma harzianum and Botrytis cinerea. Acta Phytophylacica Sinica 40(2): 191-192.

Zhang, X., Liu, Z., Tian, N., Luc, N.T., Zhu, B. \& Bing, Y. 2015. Allelopathic effects of decomposed leaf litter from intercropped trees on rape. Turkish Journal of Agriculture and Forestry 39(6): 898-908.

Zhang, X., Liu, Z. \& Hu, W. 2016. Response of nutrient release of Periploca sepium litter to soil petroleum contamination. CLEAN-Soil, Air, Water 44(12): 1709-1716.

Zheng, Y. 2008. Antibitic functions and volatile organic compounds from Pinus tabulaeformis Var. Mukdensis Uyeki and Betula Platyphlla Suk. Northeast Forestry University.

Zhou, B., Han, L., Yin, Y., Wu, J., Sun, C., Ye, X. \& Bai, L. 2010. Effects of allelochemicals hexadecanoic acid on soil microbial composition and biomass in rhizosphere of eggplant. Journal of Shenyang Agricultural University 41(3): 275-278.
Zhou, B., Kong, C.H., Li, Y.H., Wang, P. \& Xu, X.H. 2013. Crabgrass (Digitaria sanguinalis) allelochemicals that interfere with crop growth and the soil microbial community. Journal of Agricultural and Food Chemistry 61(22): 53105317.

Xiaoxi Zhang, Hui Liu, Wenxing Zhou, Jiajia Li, Hangyu Lei \& Yongkang Ji

Shaanxi Engineering and Technological Research Center for Conservation and Utilization of Regional Biological Resources College of Life Sciences, Yan'an University

Yan'an, Shaanxi, 716000

China

\section{Xiaoxi Zhang}

Institute of Soil and Water Conservation, Northwest A\&F University

Yangling, Shaanxi, 712100

China

Boya Wang \& Zengwen Liu*

College of Natural Resources and Environment

Northwest A\&F University

Yangling, Shaanxi, 712100

China

*Corresponding author; email: zengwenliu2003@aliyun.com

Received: 28 July 2018

Accepted: 4 January 2019 